\title{
Characterization and transcriptional profiles of Engraulis encrasicolus' GnRH forms
}

\author{
Andrea Miccoli ${ }^{1,2}$, Ike Olivotto ${ }^{1}$, Andrea De Felice ${ }^{2}$, Iole Leonori ${ }^{2}$ and Oliana Carnevali ${ }^{1}$ \\ ${ }^{1}$ Department of Life and Environmental Sciences, Università Politecnica delle Marche, \\ Ancona, Italy and ${ }^{2}$ CNR-National Research Council of Italy, ISMAR-Marine Sciences Institute, Ancona, Italy \\ Correspondence should be addressed to O Carnevali; Email: o.carnevali@univpm.it
}

\begin{abstract}
The European anchovy Engraulis encrasicolus, a member of the Clupeiformes order, holds a great biological and economical importance. In the past, this species was mostly investigated with the aim of assessing its reproductive biology, trophic ecology, population dynamics and the relations existing with the physical environment. At present days, though, an almost complete lack of information afflicts its neuroendocrinology and reproductive physiology. The hypothalamic-pituitary-gonadal (HPG) axis at its highest levels was herein investigated. In this study, the gonadotropin-releasing hormone (GnRH), a neuropeptide underlying many reproduction-related processes, the most critical of which is the stimulation of gonadotropin synthesis and secretion from the pituitary gland, was cloned. Three forms (salmon GnRH, chicken-II GnRH and the species-specific type) were characterized in their full-length open-reading frames and, in accordance with other Clupeiformes species, the distinctive one was found to be the herringtype GnRH. We qualitatively and semiquantitatively evaluated the localizations of expressions and the temporal transcription patterns of the three GnRH forms in male and female specimens throughout their reproductive cycle as well as described their phylogeny with regard to teleost GnRH lineages, and, specifically, to other Clupeiformes species.

Reproduction (2016) $152727-739$
\end{abstract}

\section{Introduction}

The hypothalamic-pituitary-gonadal (HPG) axis is the principal endocrine reproductive axis in vertebrates (Abraham 2004). It ensures the development, maturation and release of gametes and allows a successful reproductive process (Baba et al. 1971, Matsuo et al. 1971, Schally et al. 1971b). One of its main characters is the gonadotropin-releasing hormone $(\mathrm{GnRH})$, a hypothalamic neuropeptide involved at the earliest stages of the reproductive process. Hypophysiotropic form of the neurohormone is released from the hypothalamus to the pituitary through the mammalian hypothalamic-hypophyseal blood portal or via direct neuronal innervations of the fish pituitary stalk as both environmental and physiological cues are integrated and transduced. The processed $\mathrm{GnRH}$ decapeptide regulates the synthesis and secretion of the folliclestimulating hormone and luteinizing hormone (Schally et al. 1971a) from the anterior part of the pituitary gland - adenohypophysis (Kim et al. 1995) - by stimulating the expression of the glycoprotein hormone $\alpha(\mathrm{GP} \alpha)$ and $\beta$-subunits of the gonadotropins (Yaron et al. 2003), therefore initiating steroidogenesis and gametogenesis (Millar 2005, Kah et al. 2007).
Throughout evolutionary times, the $\mathrm{GnRH}$ gene underwent duplication events followed by subsequent nucleotide substitutions. All species investigated to date express more than one $\mathrm{GnRH}$ variant in their brain (e.g. Fernald \& White 1999, Adams et al. 2002); specifically, primitive teleosts possess two different GnRH forms, whereas more recent species have three (Dubois et al. 2001). Differences pertain to the controlled processes, the brain and pituitary concentrations, and the anatomical brain localizations (Holland et al. 1998, Carolsfeld et al. 2000).

To date, $30 \mathrm{GnRH}$ isoforms were characterized in vertebrate and invertebrate species (Roch et al. 2011), and only eight in teleosts (Adams et al. 2002). The decapeptides always display characteristics that have been maintained for more than 500 million years of evolution (King \& Millar 1980): residues 1-4 at the $\mathrm{NH}_{2}$ terminus (pGlu-His-Trp-Ser) and 9-10 at the $\mathrm{COOH}$ terminus (Pro-Gly- $\mathrm{NH}_{2}$ ) are fully conserved and fundamental for ligand recognition, binding and activation of cognate receptors (Guilgur et al. 2007); positions 5, 7 and 8 are the most variable, whereas the molecule bends around position 6, typically a Gly. This is usually substituted by D-amino acids in the 
construction of agonist analogues designed to display a higher stability and a decreased metabolic clearance (Millar 2005).

Based on phylogenetic analyses, Fernald and White (1999) classified three groups of GnRHs. GnRH1 lineage includes variants with proven hypophysiotropic functions. Among these are the mammalian - $\mathrm{m}-$ (Amoss et al. 1971), dogfish - dg - (Lovejoy et al. 1992), catfish - cf - (Bogerd et al. 1994), seabream sb - (Powell et al. 1994), medaka - md - (Okubo et al. 2000) and herring - hr - (Carolsfeld et al. 2000) GnRHs. The second group comprises the most ancient form identified to date in Gnathostoma, which is as well the most conserved across all vertebrate species (Powell et al. 1994, Chen \& Fernald 2008), the chicken-II GnRH (cGnRH-II) (Miyamoto et al. 1984). It was proposed to possess a neuromodulatory role affecting sexual behaviour rather than stimulating gonadotropin release (Maney et al. 1997, Volkoff \& Peter 1999). At last, clade 3 comprehends a GnRH variant named salmon - s - (Sherwood et al. 1983), so far described only in teleosts. Its presence is not constant and its roles depend on the overall number of $\mathrm{GnRH}$ isoforms coexisting in a given species: in those displaying two GnRH isoforms, for example sockeye salmon Oncorhynchus nerka (Parhar et al. 1995), goldfish Carassius auratus (Lin \& Peter 1997), zebrafish Danio rerio (Steven et al. 2003) and some catfish (Dubois et al. 2001), sGnRH exerts a hypophysiotropic function; if a three GnRH system is presented, sGnRH has developed specific functions related to sexual behaviour, including olfaction and spawning migration (Wirsig-Wiechmann 2001), even though further information is ever increasingly being collected.

The European anchovy Engraulis encrasicolus is the only Mediterranean representative of the Engraulidae family and a member of the Clupeiformes order, a basal teleost group. It holds an elevated importance, both biologically and economically, as it contributes to transfer energy from the basal levels of the food chain and represents one of the main targets of European fishing fleets. Despite the critical roles played by the $\mathrm{GnRH}$ system in the HPG axis functioning and, therefore, reproductive physiology, no study has ever investigated the endocrine regulation of the reproductive processes in this species. In our laboratory, we filled such gap of knowledge by (i) cloning the three $G n R H$ variants and characterizing their deduced peptides, (ii) qualitatively evaluating the localization of their mRNA expression, (iii) semiquantitatively assessing mRNA abundance patterns during the entire reproductive cycle and (iv) depicting their evolutionary relationships with other teleost GnRH isoforms. A particular emphasis was placed on the Clupeiformes order, which we have contributed to broaden in this sense.

\section{Materials and methods}

\section{Sample collection}

Male and female Engraulis encrasicolus specimens at different sexual maturity stages were sampled for brain and gonad tissues during the 2015 MEDIAS research cruises (Leonori et al. 2011, MEDIAS 2012), carried out in the FAO geographical sub areas 17 ('Northern and Central Adriatic Sea') and 18 ('Southern Adriatic Sea') by the acoustic research group of the CNR-ISMAR of Ancona (Leonori et al. 2012). Samples were taken within the Data Collection Framework Regulation (Commission Regulation (EC) No. 665/2008 of the 14 July 2008). No animal experimentation was performed in this study; therefore, ethics approval was not necessary, in accordance with the Italian legislation.

Sexual maturity stages were classified according to the MEDITS working group's Instruction Manual (2012); 1: 'Immature'; 2c: 'Maturing'; 3: 'Mature/Spawner'; 4a: 'Spent'; 4b: 'Resting'. Tissues were maintained in RNAlater until processing.

\section{RNA extraction and cDNA synthesis}

Total RNA was extracted with RNAzol ${ }^{\circledR}$ RT reagent (SigmaAldrich $^{\circledR}$, R4533) following the manufacturer's instructions and eluted in RNAse-free water. Concentration was determined with the Nanophotometer TM P-Class (Implem GmbH, P330). Integrity was verified by gel red staining of $28 \mathrm{~S}$ and $18 \mathrm{~S}$ ribosomal RNA bands on a $1 \%$ agarose gel. cDNA was retrotranscribed from $3 \mu \mathrm{g}$ RNA using the Tetro Reverse Transcriptase cDNA synthesis kit (Bioline, BIO-65050). Nucleic acids were kept at $-20^{\circ} \mathrm{C}$ until use.

\section{Cloning, sequencing and ORF extension}

$\mathrm{GnRH}$ sequences of Engraulis japonicus (GenBank accession numbers JX406273, JX406274 and JX406275), a sibling species of $E$. encrasicolus distributed from the Java Sea to the Sea of Japan, were used as templates for primer design with the web-based Primer3 software (Untergasser et al. 2012). Initial amplification was obtained with primers presented in Table 1. A 3-min denaturation at $94^{\circ} \mathrm{C}$, a 35 -cycle amplification consisting of denaturation, annealing and extension for $30 \mathrm{~s}$ each at $94^{\circ} \mathrm{C}, 60^{\circ} \mathrm{C}$ and $72^{\circ} \mathrm{C}$, respectively, and a last 10 -min extension step at $72^{\circ} \mathrm{C}$ were set as protocol. PCR products were visualized on a $2 \%$ agarose gel stained with GelRed (Diatech Pharmacogenetics, 41003). Amplification yielded single-banded products of the expected size, which were excised, purified with the MinElute Gel Extraction Kit (Qiagen, 28604) and cloned into the pGEM-T vector system (Promega, A3600). DNA was sequenced using a T7 sequenase version 2.0 DNA sequencing kit (GE Life Sciences, 70770) and a dyeterminator kit (Perkin-Elmer, US82005) on an ABI PRISM DNA sequencer (Perkin-Elmer).

Results obtained from the Sanger sequencing were submitted to the BLAST suite (Madden, 2003 - http://blast.ncbi.nlm.nih. gov/Blast.cgi). 
Table 1 Oligonucleotide sequences employed for amplification of the three $E$. encrasicolus $G n R H$ isoforms and reference genes through conventional and real-time q-PCRs.

\begin{tabular}{|c|c|c|c|}
\hline & \multicolumn{2}{|c|}{ Sequence $\left(5^{\prime}-3^{\prime}\right)$} & \multirow[b]{2}{*}{ Annealing temperature $\left({ }^{\circ} \mathrm{C}\right)$} \\
\hline & Forward & Reverse & \\
\hline hrGnRH & САAGАССТСТССАGССАСТG & GCTGATCTCTGGTGTCACT & 60 \\
\hline cGnRH-II & CAGGAGGCAAGAGGGATGTG & TCGACCACTGACGCTCTCTA & 60 \\
\hline sGnRH & AACGCAGCATTGGAGGAGAA & GTGTGCGTGCATCAGTCAAG & 60 \\
\hline$\beta$-actin & CGTGACATCAAGGAGAAGCTGTGC & САGАСТСАТСGТАСТССТGСТTGC & 60 \\
\hline$E F-\alpha$ & GAGACAGCAAGAACGACCCA & AGAACTTGCAGGCGATGTGA & 60 \\
\hline
\end{tabular}

The full-length open-reading frames of the three GnRH isoforms were obtained by conventional and/or RACE PCRs. RACE CDNA from brain and gonad tissues was synthesized with the FirstChoice ${ }^{\circledR}$ RLM-RACE Kit (Life Technologies, AM1700M) as per the manufacturer's instructions. 3' RACE outer/inner primer and adapter sequences are presented in Table 2. GnRH1_F/GnRH2_F were employed in combination with 3 ' outer/inner to extend gnrh 1 and gnrh2 respectively.

Completion of the coding sequence at the $5^{\prime}$ end was achieved by means of conventional amplification. Oligonucleotide sequences designed on the partial Engraulis encrasicolus gnrh isoforms are presented in Table 2.

\section{Protein prediction, identification and multiple alignments}

The primary structures of the encoded proteins were predicted and characterized by web-based bioinformatics tools such as Expasy Translate (http://web.expasy.org/translate/), ORF Finder (http://www.ncbi.nlm.nih.gov/projects/gorf/), the BLAST suite (http://blast.ncbi.nlm.nih.gov/Blast.cgi), SignalP (Petersen et al. 2011 - http://www.cbs.dtu.dk/services/SignalP/) and SMART (Letunic et al. 2015 - http://smart.embl-heidelberg.de/).

Full-length prepro-GnRH open-reading frames were aligned with Clustal Omega v. 1.2.1 (Sievers et al. 2011 - http://www. ebi.ac.uk/Tools/msa/clustalo/) from the Multiple Sequence Alignment tools provided by the EBI website.

GnRH decapeptides of the same teleost species were aligned within each GnRH class with MUSCLE v. 3.8

Table 2 Primer sequences used for extension of E. encrasicolus' GnRH open-reading frame.

\begin{tabular}{cl}
\hline & Sequence $\left(5^{\prime}-3^{\prime}\right)$ \\
\hline $\begin{array}{c}\text { 3' }{ }^{\prime} \text { RACE } \\
\text { outer } \\
\text { primer } \\
\text { 3' }\end{array}$ & GACEAGCACAGAATTAATACGACT \\
inner \\
primer \\
3' RACE \\
adapter & CGCGGATCCGAATTAATACGACTCACTATAGG \\
GnRH1_F & CAAGACCTCTCCAGCCACTG \\
GnRH1_F1 & CAAGTGATGGAGGGTCTCCC \\
GnRH1_R1 & CATTTGCTCTGCTCATCAGGTG \\
GnRH2_F & CAGGAGGCAAGAGGGATGTG \\
GnRH2_F1 & ATACAGCTCCAGTGATGGCG \\
GnRH2_R1 & CGTCAGGGCTTCCAACAGG \\
GnRH2_R2 & GGTAGCTGCACTCTCCTGC \\
GnRH3_F1 & GAAAAAGGGATGGAGCAGGG \\
GnRH3_R1 & GGCCTTCGACCTCTTCTCAC \\
GnRH3_R2 & GGCCGTGAGAGGAATGAGAG \\
\hline
\end{tabular}

www.reproduction-online.org
(Edgar 2004 - http://www.ebi.ac.uk/Tools/msa/muscle/). The printing and shading of the alignment files were obtained with BOXSHADE v. 3.21 (http://www.ch.embnet.org/software/ BOX_form.html), with symbols representing a consensus threshold of 0.5 .

\section{RT-PCR}

RT-PCR amplification of GnRH isoforms in both sexes was performed in a MyCyclerTM Thermal Cycler (Bio-Rad, 1709703). The reaction consisted in $16 \mu \mathrm{L}$ of $2 \mathrm{x}$ concentrated Platinum ${ }^{\circledR}$ Blue PCR SuperMix (Thermo Fisher Scientific, 12580015), $2 \mu \mathrm{L}$ of $10 \mu \mathrm{M}$ specific forward and reverse primer (Table 1) and $2 \mu \mathrm{L}$ of cDNA synthesized from brain and gonad tissues sampled from M/F 2C, diluted 1:10. The thermal protocol was iterated for 35 cycles and the annealing temperature was set at $60^{\circ} \mathrm{C}$.

\section{Real-time $q P C R$}

The three $\mathrm{GnRH}$ isoforms were relatively quantified in both brain and gonad tissues of Engraulis encrasicolus males and females. Real-time qPCRs with the SYBR green method were performed in an iQ5 iCycler thermal cycler (Bio-Rad, 179-8891). Amplification conditions were optimized after several trials at different times and temperature. Annealing temperature was set at $60^{\circ} \mathrm{C}$ in all cases. The observed single peak in the dissociation (melt) curve at the end of the amplification cycle indicated the absence of primer-dimer formation and the achievement of primer specificity. Two housekeeping genes ( $e f-\alpha$ and $\beta$-actin) served as a reference for relative mRNA quantification. Oligonucleotide sequences are presented in Table 2.

\section{Phylogenetic analyses}

Phylogeny of the three gonadotropin-releasing hormone classes was inferred by analyzing $45 \mathrm{GnRH}$ sequences belonging to overall 22 teleost species, chosen independently on their evolutionary history, at both DNA and protein levels. As for DNA, a codon-based alignment was achieved with the MUSCLE algorithm (Edgar 2004) at the default parameters. The model that best described the substitution pattern was screened with the model selection (ML) analysis. Based on the lowest Bayesian Information Criterion (BIC) score, which equalled 6481.572, the maximum likelihood phylogenetic tree was constructed employing the Kimura 2-parameter (Kimura 1980) matrix-based model. The non-uniformity of evolutionary rates among sites was modelled by a discrete Gamma distribution (five categories $(+G$, parameter $=0.7635)$ ). 
As for peptides, alignment and best substitution model were performed and screened with the same above-described methods. The lowest BIC score was 4991.046 and the model used for maximum likelihood tree construction was the JonesTaylor-Thornton one (Jones et al. 1992). In addition to a discrete Gamma distribution among sites (five categories $(+G$, parameter $=7.8178)$ ), a certain fraction of sites was considered as evolutionarily invariable $(+\mathrm{I})$.

The bootstrap method, with the number of bootstrap replication set at 1000, was used to test the inferred phylogeny (Felsenstein 1985).

Phylogenetic analyses were performed with the MEGA suite v. 6 (Tamura et al. 2013), according to Hall (2013).

\section{Statistical analysis}

The differences among GnRHs' relative mRNA abundances at all sexual maturity stages were assessed for statistical significance by one-way analysis of variance (ANOVA). Data were normalized with $\ln (x+1)$ in order to homogenize the variance and fulfil conditions for applying a parametric test. The post hoc Tukey test was used for testing multiple comparisons with a confidence interval of 95\% $(P<0.05)$. Statistical analyses were performed with GraphPad Prism v. 6.

\section{Results}

\section{Engraulis encrasicolus GnRH isoforms}

The full-length coding sequences of the three GnRHs of Engraulis encrasicolus', namely hrGnRH (a speciesspecific form belonging to the GnRH1 class), cGnRH-II $(\mathrm{GnRH} 2)$ and sGnRH (GnRH3), were cloned. They were deposited into the NCBI's GenBank with the accession numbers KU323664, KU323665 and KU323666 respectively.

The partial GnRH1 cDNA consisted of 434 nt and contained a full-length open-reading frame of 267 nt. The encoded protein was 88-aa long and included a predicted signal peptide of 22 residues (Fig. 1A). Its deduced amino acid sequence was pGlu-His-Trp-SerHis-Gly-Leu-Ser-Pro-Gly- $\mathrm{NH}_{2}$. Nucleotide alignment analysis yielded very few results, indicating the low identity with other species-specific GnRH sequences. BLASTn similarity rates to Engraulis japonicus and Alosa sapidissima forms accounted for $95 \%$ and $70 \%$ (data not shown), whereas amino acid identity was 93.18\% and $55.81 \%$ (Table 3 ) respectively. A complete conservation among GnRH decapeptides was shown by a MUSCLE alignment and a BOXSHADE shading (Fig. 2A).

As for GnRH2, we successfully obtained its cDNA, full-length at the $3^{\prime}$ end. It consisted of $624 \mathrm{nt}$, with a full-length open-reading frame of $261 \mathrm{nt}$ encoding for an 86-aa protein. The predicted signal peptide was 24 residues long. A BLASTn search resulted in a $98 \%$ and 85\% identity with the Engraulis japonicus and Clupea harengus GnRH2 forms (data not shown), whereas the average amino acidic similarity to other teleosts'

\section{A hrGnRH}

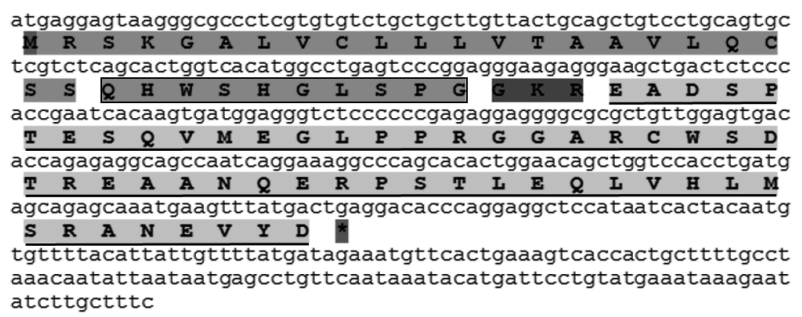

\section{B cGnRH-II}
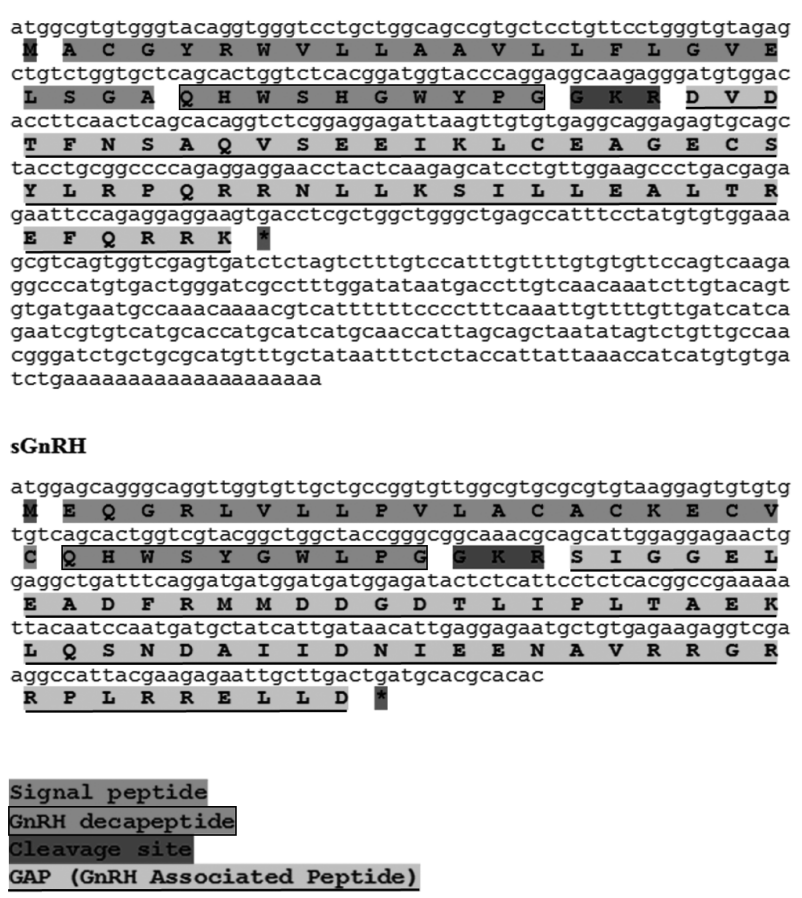

Figure $1 \mathrm{CDNA}$ sequence and deduced primary structures of hrGnRH (GnRH1) (A), cGnRH-II (GnRH2) (B) and sGnRH (GnRH3) (C). The initial methionine is highlighted in green colour, whereas the stop codon is indicated by an asterisk highlighted in red colour. Conserved regions such as signal peptides, GnRH decapeptides, Gly-Lys-Arg cleavage sites and $\mathrm{GnRH}$-associated peptides are shown according to the figure legend.

cGnRH-II was $67.45 \%$, with E. japonicus showing the highest degree of $100 \%$ (Table 3 and Fig. 2B).

Cloning of the GnRH3 cDNA yielded a partial sequence of $281 \mathrm{nt}$ containing a full-length openreading frame of $270 \mathrm{nt}$. The encoded protein was 89 residues long and 21 aa composed the signal peptide. The degree of similarity to E. japonicus sGnRH (GnRH3) at DNA and protein levels was 97\% (data not shown) and $94.38 \%$ (Table 3) respectively. Homology with other teleosts' sGnRH ranged from $42.05 \%$ (C. auratus) to $45.05 \%$ (D. rerio) (Table 3 ). The decapeptide had a completely conserved primary structure among several analyzed teleosts (Fig. 2C).

Apart from the signal peptide at the $\mathrm{N}$-terminus and the typical GnRH decapeptide (highlighted in light grey colour and boxed respectively), the primary structures of 
Table 3 Degree of identity among several teleost prepro-GnRH isoforms assessed at the full-length ORF level, expressed as percentages. The analyses was conducted with Clustal Omega multiple sequence alignment tool (http://www.ebi.ac.uk/Tools/msa/ clustalo/). Refer to caption of Fig. 2 for information regarding GenBank accession numbers of the protein entries used for similarity assessment. Comparisons between Engraulis spp. are underlined.

\begin{tabular}{lccc}
\hline & \multicolumn{3}{c}{ \% of AA identity } \\
\cline { 2 - 4 } & \multicolumn{3}{c}{ E. encrasicolus } \\
\cline { 2 - 4 } GnRH form (species) & hrGnRH & cGnRH-II & sGnRH \\
\hline hrGnRH (E. japonicus) & $\underline{\mathbf{9 3 . 1 8}}$ & 25.32 & 21.33 \\
hrGnRH (E. encrasicolus) & I & 25.32 & 20.00 \\
wfGnRH (C. clupeaformis) & $\mathbf{2 8 . 7 4}$ & 25.30 & 28.21 \\
mdGnRH (O. latipes) & $\mathbf{2 5 . 8 8}$ & 18.75 & 20.78 \\
sbGnRH (S. aurata) & $\mathbf{2 6 . 4 4}$ & 23.46 & 24.36 \\
pjGnRH (M. albus) & $\mathbf{3 0 . 6 8}$ & 20.48 & 20.00 \\
sbGnRH (D. labrax) & $\mathbf{2 8 . 4 1}$ & 21.69 & 23.75 \\
sbGnRH (M. undulatus) & $\mathbf{2 3 . 5 3}$ & 22.78 & 27.27 \\
sbGnRH (M. cephalus) & $\mathbf{3 3 . 7 2}$ & 21.95 & 24.05 \\
sbGnRH (H. burtoni) & $\mathbf{2 6 . 1 4}$ & 25.00 & 22.89 \\
sbGnRH (O. niloticus) & $\mathbf{2 6 . 1 4}$ & 23.81 & 22.89 \\
cfGnRH (C. gariepinus) & $\mathbf{3 7 . 3 3}$ & 35.06 & 19.44 \\
hrGnRH (A. sapidissima) & $\mathbf{5 5 . 8 1}$ & 29.87 & 21.33 \\
cGnRH-II (E. japonicus) & 25.32 & $\mathbf{1 0 0 . 0 0}$ & 27.27 \\
cGnRH-II (E. encrasicolus) & 25.32 & $/$ & 27.27 \\
cGnRH-II (C. auratus) & 25.32 & $\mathbf{5 6 . 9 8}$ & 28.57 \\
cGnRH-II (C. gariepinus) & 25.32 & $\mathbf{6 2 . 7 9}$ & 29.87 \\
cGnRH-II (A. japonica) & 28.75 & $\mathbf{6 5 . 1 2}$ & 34.62 \\
cGnRH-II (O. mykiss) & 30.38 & $\mathbf{6 1 . 7 3}$ & 28.57 \\
cGnRH-II (O. latipes) & 29.73 & $\mathbf{6 7 . 5 0}$ & 29.33 \\
cGnRH-II (M. cephalus) & 29.11 & $\mathbf{6 5 . 8 8}$ & 27.63 \\
cGnRH-II (H. burtoni) & 29.11 & $\mathbf{6 5 . 8 8}$ & 27.63 \\
cGnRH-II (O. niloticus) & 29.11 & $\mathbf{6 5 . 8 8}$ & 27.63 \\
cGnRH-II (S. aurata) & 30.38 & $\mathbf{6 4 . 7 1}$ & 28.95 \\
cGnRH-II (M. saxatilis) & 26.58 & $\mathbf{6 7 . 0 6}$ & 28.95 \\
cGnRH-II (D. labrax) & 27.85 & $\mathbf{6 5 . 8 8}$ & 28.95 \\
sGnRH (E. japonicus) & 21.33 & 28.57 & $\mathbf{9 4 . 3 8}$ \\
sGnRH (E. encrasicolus) & 20.00 & 27.27 & $/$ \\
sGnRH (P. major) & 25.61 & 29.49 & $\mathbf{4 4 . 4 4}$ \\
sGnRH (S. aurata) & 25.61 & 29.49 & $\mathbf{4 4 . 4 4}$ \\
sGnRH (D. labrax) & 24.39 & 30.77 & $\mathbf{4 4 . 4 4}$ \\
sGnRH (H. burtoni) & 23.17 & 32.05 & $\mathbf{4 3 . 2 1}$ \\
sGnRH (O. latipes) & 26.83 & 30.77 & $\mathbf{4 4 . 4 4}$ \\
sGnRH (O. masou) & 20.51 & 28.57 & $\mathbf{4 5 . 2 1}$ \\
sGnRH (D. rerio) & 22.50 & 27.85 & $\mathbf{4 5 . 4 5}$ \\
sGnRH (C. auratus) & 21.25 & 31.65 & $\mathbf{4 2 . 0 5}$ \\
sGnRH (C. nebulosus) & 24.39 & 30.77 & $\mathbf{4 4 . 4 4}$ \\
sGnRH (C. carpio) & 22.50 & 27.85 & $\mathbf{4 3 . 1 8}$ \\
sGnRH (M. cephalus) & 25.61 & 29.49 & $\mathbf{4 2 . 6 8}$ \\
sGnRH (O. niloticus) & 24.69 & 33.33 & $\mathbf{4 4 . 3 0}$ \\
\hline & \multicolumn{3}{|c}{}
\end{tabular}

the three isoforms displayed conserved domains, such as the Gly-Lys-Arg (GKR) cleavage site and a 56-, 52and 58-aa long $\mathrm{GnRH}$-associated peptide (GAP) at the C-terminus, respectively, highlighted in dark grey colour and underlined (Fig. 1).

\section{RT-PCR}

A qualitative assessment of GnRH mRNA expressions was performed in brain and gonad tissues of stage 2C ('Maturing') female and male of E. encrasicolus (Fig. 3). After 35 cycles, three bands of distinct expected sizes were evident on a $2 \%$ agarose gel. Products were sequenced to confirm their identity of $\mathrm{GnRH}$-specific amplicons. The three gnrhs were always transcribed, although not all isoforms were expressed with the same extent and they were found being more faintly expressed in males than in females. Male $\mathrm{CGnRH-II}$ appeared more evident in the brain than the gonad. Female $s G n R H$ transcriptions, although more noticeable than in males, had different band intensities between tissues and the one at the central level was more marked than the gonad's. Two housekeeping genes were included, namely ef-a and b-actin. All precautionary measures were taken to avoid contamination of the samples. A negative control was included in the analyses and indicated as no template control in Fig. 3.

Altogether, these results demonstrate that the European anchovy possesses three distinctive $\mathrm{GnRH}$ forms that can be subjected to modulated tissue transcription at the 'Maturing' sexual developmental stage.

\section{Real-time $q P C R s$}

Relative mRNA abundances of herring-, chicken-II- and salmon-type $\mathrm{GnRH}$ s were investigated semiquantitatively throughout the reproductive cycle of female (Fig. 4) and male (Fig. 5) Engraulis encrasicolus specimens in brain and gonad tissues. GnRH types were always expressed in both tissues. Brain hrGnRH transcription displayed similar trends in both sexes (Figs 4A and 5A). Statistically significant variations in mRNA abundances occurred at stages 2c, 3 and 4a ('Maturing', 'Mature/Spawner' and 'Spent'). Transcription of $s G n R H$ in female brain (Fig. 4E) followed a similar pattern, which was supported by statistical significance at the reproductively active stages. The highest transcription values were found at the spawning phase.

Ovaries and testicles had different $h r G n R H$ mRNA levels, and it was not possible to describe a general trend (Figs $4 \mathrm{~B}$ and $5 \mathrm{~B}$ ). The formers had a statistically significant 2.5-fold higher abundance of type $1 \mathrm{GnRH}$ in the maturing phase and lower non-significant levels among F3, F4a and F4b stages. The latters had the lowest hrGnRH transcription value at spawning, whereas mRNA levels were similar at the remaining stages.

Despite with different extent, female gonad and male brain had comparable cGnRH-II transcription trends (Figs 4D and 5C), which significantly increased from maturing to spawning individuals and declined in fish that had reached the resting stage. $s G n R H$ and cGnRH-II in female gonad (Figs 4D and 4F) were transcribed similarly.

Gene expression of $\mathrm{CGnRH}-\mathrm{Il}$ in female brain (Fig. 4C) significantly increased from immature to reproductively active fish and remained at comparable levels throughout the reproductive cycle, as indicated by the lack of statistically significant differences. 


\section{A}

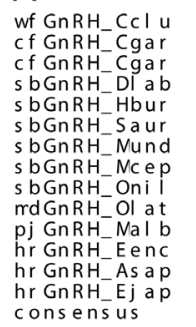

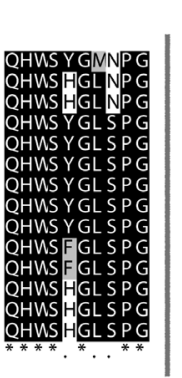

GnRH1

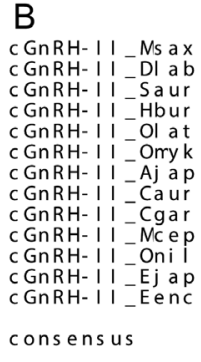

$\mathrm{GnRH} 2$

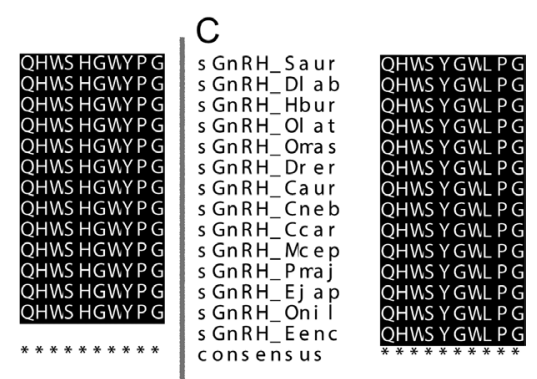

GnRH3

Figure 2 Multiple alignments of teleost $\mathrm{GnRH} 1$ (A), GnRH2 (B) and $\mathrm{GnRH} 3$ (C) decapeptides. Identical, conservative and unrelated residues are shaded in black, grey and white colour respectively. GenBank accession numbers are as follows: GnRH1: C. clupeaformis AAP57221.1, O. latipes BAB16303.1, S. aurata AAA75469.1, M. albus AAW51121.1, D. labrax AAF62898.1, M. undulatus AAQ16501.2, M. cephalus AAQ83269.1, H. burtoni AAC59691.1, O. niloticus BAC56849.1, C. gariepinus CAA54971.1, A. sapidissima AAN04492.1, E. japonicus AFO70217.1, E. encrasicolus KU323664.1. GnRH2: E. japonicus AFO70218.1, E. encrasicolus KU323665.1, C. auratus AAC59858.1, C. gariepinus CAA54969.1, A. japonica BAA82609.1, O. mykiss AAB82559.1, O. latipes BAB16300.1, M. cephalus AAQ83270.1, H. burtoni AAA74993.1, O. niloticus BAC56850.1, S. aurata AAA75447.1, M. saxatilis AAD03816.1, D. labrax AAF62900.1. GnRH3: P. major BAA05104.1, S. aurata AAA98845.1, D. labrax AAF62899.1, H. burtoni AAB20243.1, O. latipes BAB16302.1, O. masou BAA01740.1, D. rerio CAC18539.1, C. auratus BAB18904.1, C. nebulosus AAV74403.1, C. carpio AAO39752.1, M. cephalus AAQ83268.1, P. major BAA05104.1, E. japonicus AFO70219.1, O. niloticus XP_013126782.1, E. encrasicolus KU323666.1.

\section{Phylogeny}

The evolutionary relationships among the GnRH forms of E. encrasicolus and those of other teleost species were inferred by the maximum likelihood method based on the JTT matrix-based model. Only the tree constructed from prepro-GnRH peptide sequences is reported, as a good correspondence between it and the one built from codon-based DNA multiple alignments was found. Figure 6 shows the tree with the highest log likelihood $(-2144.1972)$; it is drawn to scale, with branch lengths measured in the number of substitutions per site and the scale bar of 0.2, indicating the estimated evolutionary distance units. High bootstrap values supported the statistical significance of the tree's conformation.

Teleost GnRHs were clustered into three different branches and marked as GnRH1, GnRH2 and GnRH3,
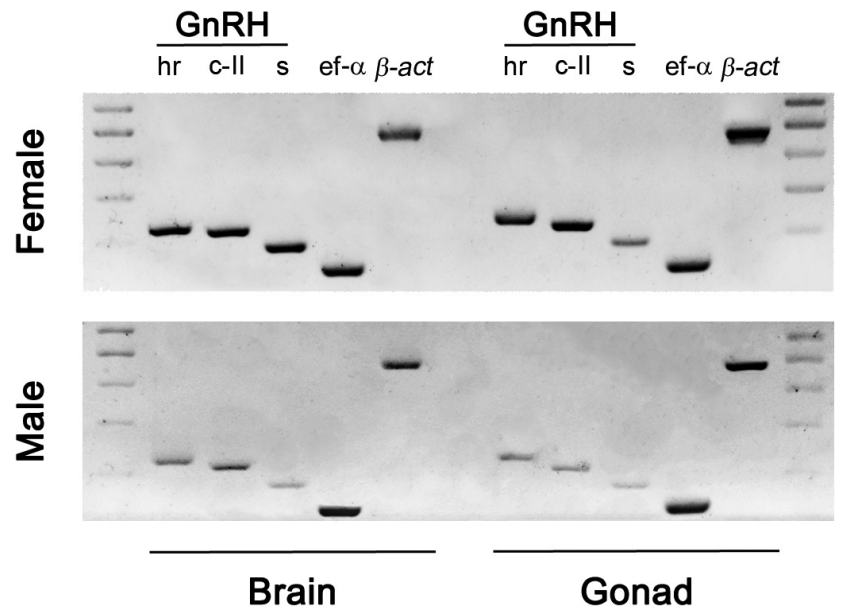

Figure 3 Qualitative tissue distribution analyses of GnRH isoforms assessed in the brain and gonads of stage 2c ('Maturing') female and male Engraulis encrasicolus after 35 cycles of RT-PCR amplification. ef- $\alpha$ and $\beta$-actin were used as reference genes.
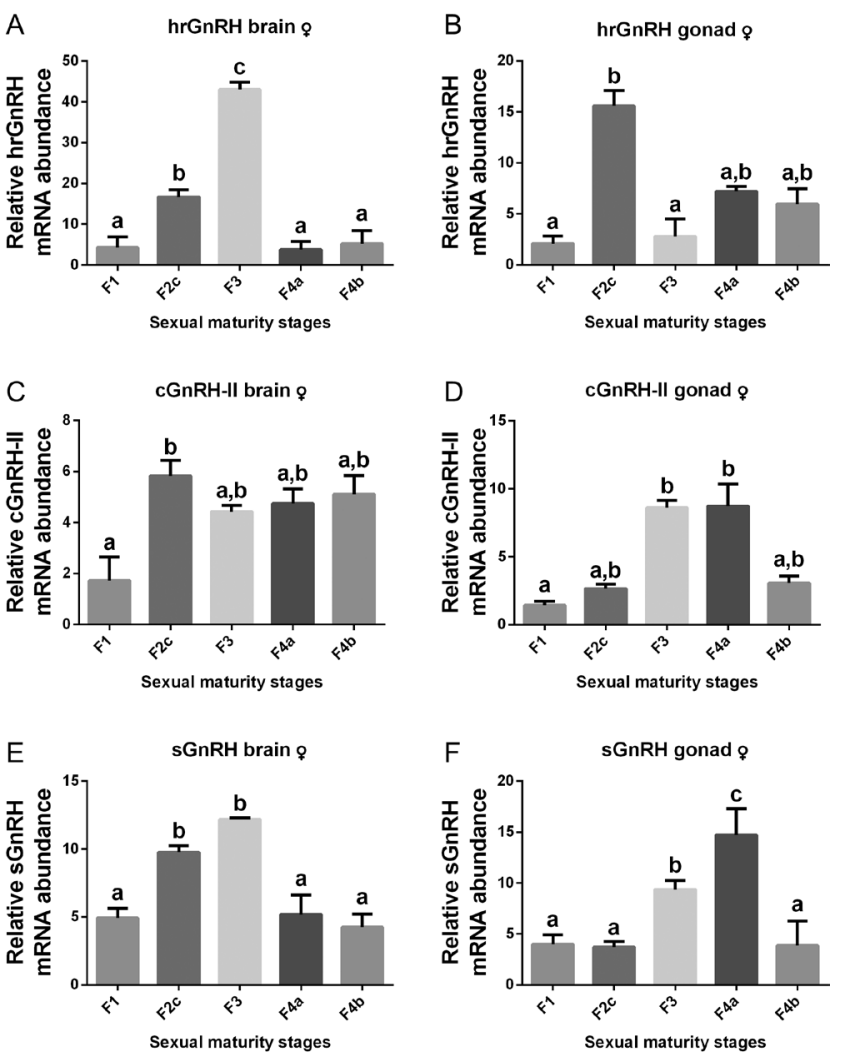

Figure 4 Semiquantitative measurement of mRNA abundance of the three GnRH types throughout the reproductive cycle of female Engraulis encrasicolus in the brain and gonad. The calculation was made over two reference genes, ef- $\alpha$ and $\beta$-actin. Letters represent statistical significance $(P<0.05)$ between two consecutive sexual maturation stages, as indicated by the one-way ANOVA and the post hoc Tukey test. 

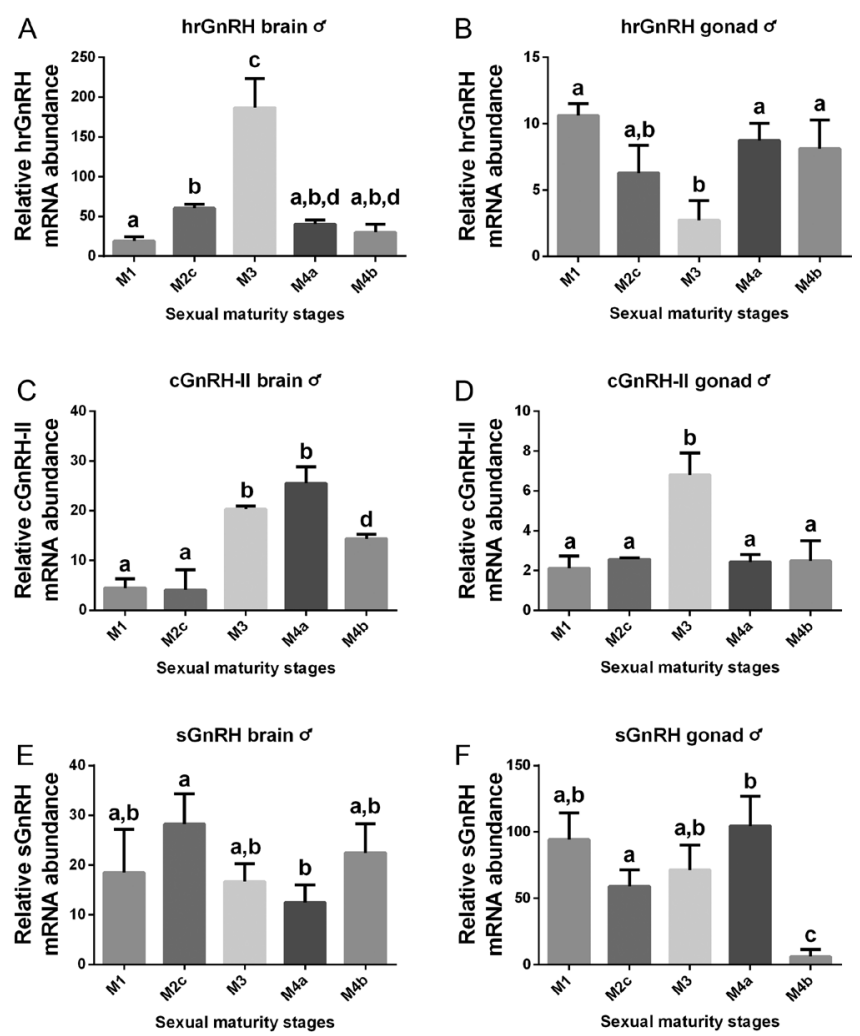

Figure 5 Semiquantitative measurement of mRNA abundance of the three $\mathrm{GnRH}$ types throughout the reproductive cycle of male Engraulis encrasicolus in the brain and gonad. The calculation was made over two reference genes, ef- $\alpha$ and $\beta$-actin. Letters represent statistical significance $(P<0.05)$ between two consecutive sexual maturation stages, as indicated by the one-way ANOVA and the post hoc Tukey test.

grouping all species-specific GnRHs, all cGnRH-Il sequences and all salmon-type $\mathrm{GnRH}$ s respectively. E. encrasicolus had a $\mathrm{GnRH}$ representative in each subgroup. Its forms always strongly correlated with the homologs of the Japanese anchovy, as represented by the bootstrap values of 100 in all the three cases.

The clade clustering salmon-type GnRHs appeared to be more equally distributed than the other two, as five evolutionary-distant orders (Perciformes, Mugiliformes, Salmoniformes, Beloniformes and Cypriniformes) were enclosed in only two $79 \%$ bootstrapped subgroups. The former four were included in only one branch. GnRH3-wise, Clupeiformes' Engraulis spp. shared a common ancestor with other taxa but were shown to have undergone a more ancient speciation event and therefore occupied a detached position.

As for the species-specific form, E. encrasicolus, E. japonicus and A. sapidissima (three Clupeiformes species) were closely related. Interestingly, herringtype GnRH seemed to have a common shared ancestor with the euryhaline Anguilliformes A. japonica and the freshwater Salmoniformes C. clupeaformis.

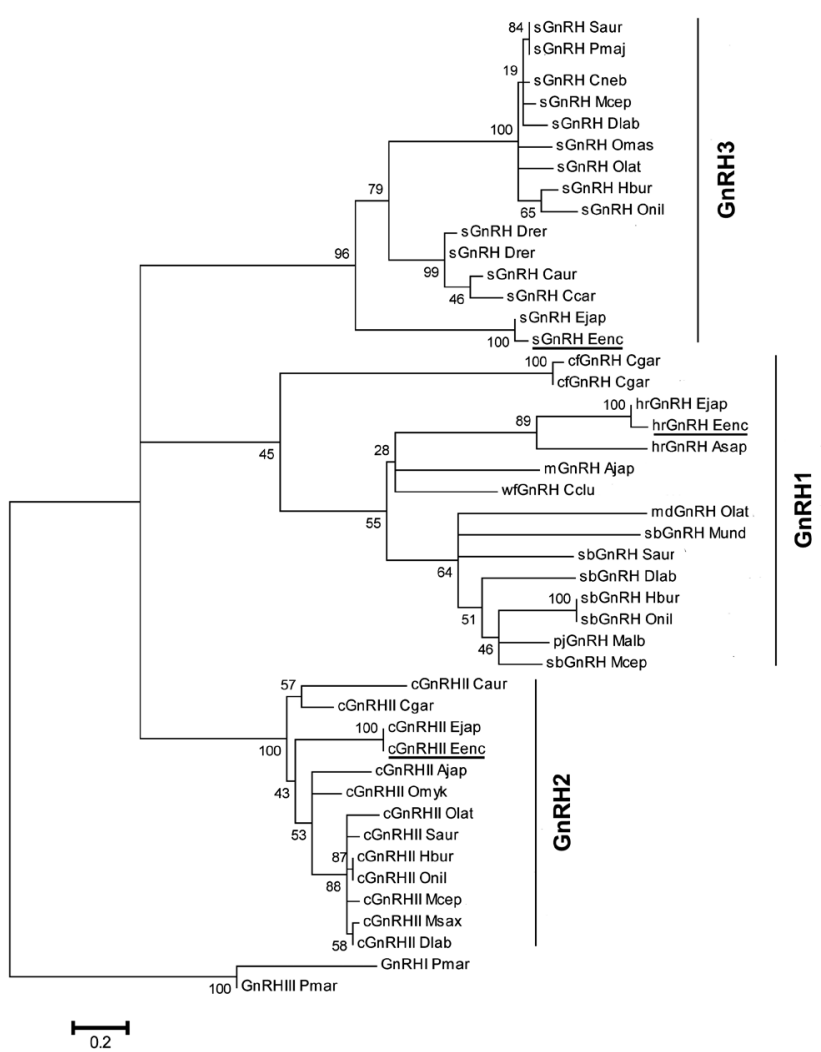

Figure 6 Rooted phylogenetic tree built with Mega v. 6 using 45 teleost prepro-GnRH sequences. Relative branch lengths indicate the evolutionary rates of the lineages. Bootstrap values are reported at nodes. Accession numbers of the GenBank protein entries used for inferring the evolutionary history are reported as follows:

GnRH1 clade: cfGnRH C. gariepinus CAA54970.1, cfGnRH C. gariepinus CAA54971.1, hrGnRH E. japonicus AFO70217.1, hrGnRH E. encrasicolus KU323664, hrGnRH A. sapidissima AAN04492.1, mGnRH A. japonica BAA82608.1, wfGnRH C. clupeaformis AAP57221.1, mdGnRH O. latipes BAB16303.1, sbGnRH M. undulates AAQ16501.2, sbGnRH S. aurata AAA75469.1, sbGnRH D. labrax AAF62898.1, sbGnRH H. burtoni AAC59691.1, sbGnRH O. niloticus BAC56849.1, pjGnRH M. albus AAW51121.1, sbGnRH M. cephalus AAQ83269.1. GnRH2 clade: cGnRH-II C. auratus AAC59858.1, cGnRH-II C. gariepinus CAA54969.1, cGnRH-II E. japonicus AFO70218.1, cGnRH-II

E. encrasicolus KU323665, cGnRH-II A. japonica BAA82609.1, cGnRH-II O. mykiss AAB82559.1, cGnRH-II O. latipes BAB16300.1, cGnRH-II S. aurata AAA75447.1, cGnRH-II H. burtoni AAA74993.1, cGnRH-II O. niloticus BAC56850.1, cGnRH-II M. cephalus AAQ83270.1, cGnRH-II M. saxatilis AAD03816.1, cGnRH-II D. labrax AAF62900.1. GnRH3 clade: sGnRH S. aurata AAA98845.1, sGnRH P. major BAA05104.1, sGnRH C. nebulosus AAV74403.1, sGnRH M. cephalus AAQ83268.1, sGnRH D. labrax AAF62899.1, sGnRH O. masou BAA01740.1, sGnRH O. latipes BAB16302.1, sGnRH H. burtoni AAB20243.1, sGnRH O. niloticus XP_013126782.1, sGnRH D. rerio CAC18539.1, sGnRH D. rerio NP_878307.2, sGnRH C. auratus BAB18904.1, sGnRH C. carpio AAO39752.1, sGnRH E. japonicus AFO70219.1, sGnRH E. encrasicolus KU323666. Out-group: GnRH-I P. marinus AAF78455.1, GnRH-III P. marinus AAL12249.1. GnRH types of E. encrasicolus are underlined. 
Two candidates, GnRH-I and GnRH-III, belonging to P. marinus (a jawless species of the Agnatha superclass), grouped outside of the three clusters and were chosen as tree root accordingly to the out-group method.

\section{Discussion}

Investigations carried out so far on the European anchovy Engraulis encrasicolus (e.g. Millán 1999, Allain et al. 2007, Schismenou et al. 2012, Basilone et al. 2013, Giannoulaki et al. 2013) have mostly focused on understanding the relationship of the species with the physical environment as well as assessing pure biological parameters rather than taking into consideration its neuroendocrinology. Except for one previous contribution (Miccoli et al. 2016), such species lack of a physiological perspective and, at present days, the hypothalamic-hypophyseal-gonadal (HPG) axis is completely uncharacterized.

In this study, the components of the GnRH system of E. encrasicolus were described for the first time. With no genomic resource available, we initially hypothesized the scenario of this species to be consistent with those of other Clupeiformes members, specifically the herring Clupea harengus pallasii (Carolsfeld et al. 2000), the shad Alosa sapidissima (Abraham 2004) and the Japanese anchovy Engraulis japonicus (Sukhan et al. 2013).

We cloned three GnRH forms -hr, c-II and s- (Figs 1 and 2), demonstrating that in the European anchovy as in the large majority of modern teleosts - multiple variants regulate additional processes other than stimulating the release of the two gonadotropins (Dubois et al. 2001, Zohar et al. 2010). We were always successful in obtaining the full-length open-reading frames and therefore the complete prepro-GnRHs (Fig. 1). Despite the mature decapeptide is generated by a post-translational processing of the GnRH precursor (Wańkowska \& Polkowska 2009), the current view on reproductive neuroendocrine mechanisms could be broadened by characterizing the regions external to the $\mathrm{GnRH}$ decapeptide, as these were found to possess biological activeness (Millar et al. 1986).

GnRH1 of E. encrasicolus was coherent with the herring-type GnRH (Carolsfeld et al. 2000). hrGnRH shares a high decapeptide identity with the medaka (Okubo et al. 2000), seabream (Powell et al. 1994) and catfish (Bogerd et al. 1994) GnRH types. Compared with $\mathrm{md}$ and $\mathrm{sb}$, the only dissimilar amino acids are at position 5 ( $\mathrm{H}$ vs $\mathrm{F}$ and $\mathrm{Y}$ respectively), whereas divergence between $\mathrm{hr}$ and cf occurs at residue 8 ( $\mathrm{S}$ vs N) (Fig. 2A). In relation to $\mathrm{mGnRH}$, positions 5 and 8 differ. The situation we highlighted by BOXSHADE alignment is in line with that described by Gothilf et al. (1995) and Okubo et al. (2000). Considering the currently available information on the order and our results, we speculate that $\mathrm{hr}$ is the standard Clupeiformes-specific $\mathrm{GnRH}$ type.
A typical vertebrate GnRH structure AA-wise (Cheng \& Leung 2005, Kah et al. 2007) was confirmed in all the three cases. The protein organization comprises a 21-24 residue long leucine-rich signal peptide, a GnRH decapeptide, a GKR processing site and a 52-58 aa-long $\mathrm{GnRH}$-associated peptide (GAP). The functional roles of the majority of the peptide regions are established, except for GAP. Most authors agree that it ensures the precursor's proper folding and assists in the gonadotropin release (Millar et al. 1986, Yu et al. 1988). In mice, mutations on exon 3 and 4 encoding for most of the GAP region prevented GnRH secretion, ultimately leading to sexual immaturity (Seeburg et al. 1987). This region seems to have diverged the most both within and between species (Lin et al. 1998). GAPs of prepro$\mathrm{GnRH} 2$ and three of seabass Dicentrarchus labrax share an average inter-species identity of $93 \%$ while that of prepro-GnRH1 ranges between 35 and $57 \%$, suggesting that the species-specific gene variant underwent a much faster evolution (Zohar et al. 2010). In other terms, we presented a similar result by investigating amino acid identity among several teleost prepro-GnRHs species (Table 3). The most divergent class was indeed found to be $\mathrm{GnRH} 1$, whereas the one sharing the highest similarity was the $\mathrm{GnRH} 2$, further outlining the strong but differential evolutionary pressure that acted on discrete GnRH forms.

Through immunohistochemistry, in situ hybridization and transgenesis analyses, a general pattern of $\mathrm{GnRH}$ types' localization was previously documented (Okubo \& Nagahama 2008, Zohar etal. 2010). The reproductively relevant GnRH1 neurons predominantly distribute in the ventral forebrain, mainly in the pituitary-innervating preoptic area, and in the hypothalamus; the conserved cGnRH-II is located in the midbrain tegmentum; if the third teleost-specific sGnRH is present, it is found at the terminal nerve ganglion (Gothilf et al. 1996). However, an overlapping distribution of $\mathrm{GnRH} 1$ and 3 in the olfactory bulbs was described in the seabass (GonzálezMartínez et al. 2001), lake whitefish (Vickers et al. 2004), medaka (Okubo et al. 2006), Atlantic croaker (Mohamed et al. 2005), American cichlid (Pandolfi et al. 2005) pejerrey (Guilgur et al. 2007) and Japanese anchovy (Sukhan et al. 2013). Even though our study was not aimed at and did not describe the spatial localization of any $\mathrm{GnRH}$ neurons in the European anchovy, because of the cited evidences and particularly the one referring to the Japanese sibling, we speculate that $E$. encrasicolus displays a similar situation. However, an ad hoc study is necessary to demonstrate this hypothesis.

The multiple tasks of such a widely distributed $\mathrm{GnRH}$ system were first inferred and later demonstrated by evidences based on anatomical distributions occupied. Although cGnRH-II could stimulate gonadotropin release in vitro (Bosma et al. 2000), its capability in vivo was extremely low, likely because its neurons do not 
project into the pituitary (Amano et al. 2002) but are instead localized in areas associated with reproductive behaviour (Millar 2005) and enter the spinal cord (Carolsfeld et al. 2000). Confirmation was achieved when sexual arousal in rodents (e.g. Rissman et al. 1997) and energy coordination in the musk shrew (Temple et al. 2003) were demonstrated to depend on it. $\mathrm{GnRH} 2$ is also involved in (i) the release of melatonin (Servili et al. 2010) and growth hormone (Trudeau 1997) as well as regulation of prolactin (Weber et al. 1997) and somatolactin (Kakizawa et al. 1997); (ii) the control of isotocin/vasotocin electrical activities (Saito et al. 2003) and synaptic transmission (Kinoshita et al. 2007); and (iii) autocrine/paracrine processes (Millar 2005). As neurons localized in the terminal nerve ganglion are able to integrate olfaction and sight, $\mathrm{GnRH} 3$ was proposed to serve neuromodulatory roles (Sukhan et al. 2013), particularly referred to sexual behaviour (Yamamoto et al. 1997, Ogawa et al. 2006) and environmental stimuli (Kudo et al. 1996). In Actinopterygii, first ( 400 MYA), and true bony fish (Teleostei), then ( 145 MYA), such an expanded GnRH system represented an evolutionary advantage, as a refined control of reproduction was likely one of the factors that increased offspring survival, especially in batch-spawning species that release their gametes in schools (Carolsfeld et al. 1996), ultimately facilitating fish evolutionary radiation and their phenotypic diversification (Nelson 1994). As a possible direct result, nowadays bony fish embrace more than 20,000 species, equalling approximately one third of all vertebrates (Yaron et al. 2003).

A number of papers about teleost and other vertebrate groups such as mammals and reptiles (Uzbekova et al. 2001, Ikemoto \& Park 2003) report peripheral $\mathrm{GnRH}$ mRNA expression in the gonads, eyes, olfactory epithelium and gills. In those tissues, the system was suggested to take part in additional functions related to reproduction (autocrine/paracrine roles, chemosensory processes and osmoregulation respectively) (Guilgur et al. 2007). Considering these data, we employed stage $2 \mathrm{c}$ male and female specimens to perform a qualitative analysis (Fig. 3). $h r$, $c-I I$ and $s G n R H$ types were transcribed at both central and peripheral levels even though mRNA abundances were not always comparable. Likely, such distributions confirm the involvement of the different GnRH forms into processes related to the detection of environmental stimuli (e.g. photoperiod, lunar cycle and temperature), which are perceived and integrated at a central level in order to trigger the reproductive process at the most favourable period of the year. Our findings represent the first indication of the functional specialization to which GnRH types of $E$. encrasicolus were subjected. Retrieving evidences about the presence of the $\mathrm{GnRH}$ pathway in the gonads of further teleost species could contribute to reinforce the hypothesis proposed by Powell et al. (1996), who suggested a direct gonadal regulation by the $\mathrm{GnRH}$ system after several forms isolated from tunicates' neural tissue were shown able to activate the gonads.

With regard to a semiquantitative pattern of mRNA expression, the relative abundance of pituitary $h r G n R H$ in the herring was much higher than in any other forms' (Carolsfeld et al. 2000). Pituitary hrGnRH abundance in the American shad was 4- to 48-fold higher than $s G n R H$ and CGnRH-II (Abraham 2004). Our data showed that in the European anchovy, $h r G n R H$ relative abundances were 11- and 3.6-fold as well as 9.3- and 11-fold higher than $c G n R H-I /$ and $s G n R H$ in stage 3 ('Mature/ Spawner') female and male specimens respectively (Figs 4A and 5A). In teleost displaying three GnRH forms, the species-specific variant, which is the major inducer of gonadotropins release from the pituitary, is the most abundant one mRNA-wise (Powell et al. 1995, Gothilf et al. 1996). Taking this into consideration, we suggest that the herein described herring-type $\mathrm{GnRH}$ be indeed the hypophysiotropic form involved in triggering reproduction in E. encrasicolus, even though dedicated analyses, possibly at the protein level, might be useful to support our conclusions. In addition, from a pure research point of view, we could define the mRNA expression pattern throughout the reproductive cycle of both sexes, at central and peripheral levels. Ours is the first attempt performed on a Clupeiformes species, as none of the just-mentioned papers reported such an aspect. Considering the similar expression patterns of $h r$ - and $s G n R H s$ at the central level (Fig. 4A and E), we speculate about their possible evolutionary convergence, which is discussed more in details hereafter. An important information that can be deduced from comparing the three forms of $\mathrm{GnRH}$ expressions at both levels is the lack of correlation among brain and gonad mRNA trends, especially in female specimens (Fig. 4). This is likely due to the above-mentioned GnRH involvement in autocrine/paracrine processes (Millar 2005, Ramakrishnappa et al. 2005): in rainbow trout, GnRHs were shown to take part in the regulation of gonadal maturation and spawning (Gray et al. 2002); in the protandry gilthead seabream, $\mathrm{GnRH}$ was found to direct the differentiation of the switching gonad and to modulate androgen levels (Soverchia et al. 2007); in the goldfish, the GnRH system was shown to be able to induce or inhibit the apoptotic process, according to the ovarian developmental stages (Andreu-Vieyra et al. 2005). We hypothesize that a similar situation is also present in the European anchovy, but further studies are needed to specifically address this point.

The evolution of the GnRH system was inferred by analyzing a set of teleost $\mathrm{GnRHs}$ including 45 homologues from 22 species. GnRH1, GnRH2 and $\mathrm{GnRH} 3$ clades, in which European anchovy hrGnRH, cGnRH-II and sGnRH were, respectively, allocated, were shown to be monophyletic (Fig. 6). We demonstrated that the European anchovy hrGnRH is phylogenetically 
close to $\mathrm{mGnRH}$, sbGnRH, pjGnRH and wfGnRH, consistently with the findings of Abraham (2004) and Dubois et al. (2002); it grouped with other GnRH1 types known to possess hypophysiotropic functions - $\mathrm{m}$, cf, wf, $\mathrm{md}$, sb and $\mathrm{pj}^{-}$, further confirming its homology with such GnRH lineage.

The three $\mathrm{GnRH}$ variants of the Engraulis spp. were highly related to each other, as indicated by the similar branch lengths and by the bootstrap statistical test. Their relation with other Clupeiformes species could be assessed only in the case of Alosa sapidissima hrGnRH, which was placed in a separate, yet highly related, clade from Engraulis spp. despite displaying an identical branch length to that of E. encrasicolus. We could not evaluate how the evolutionary history of the American shad's cGnRH-II or sGnRH relates to the European anchovy's, as Abraham (2004) was successful in isolating only the hrGnRH type. The same applies to Clupea harengus, as Carolsfeld (2000) characterized only the decapeptide sequences of hr, c-II and sGnRHs (UniProtKB/Swiss-Prot references P81749, P68075 and P69106). As the short length and the conserved primary structure of the $\mathrm{GnRH}$ peptides prevent phylogenetic analyses from being effectively accomplished if only the mature protein is considered (Guilgur et al. 2007, Kah et al. 2007), we did not add them to the dataset to be analyzed.

According to King and Millar (1992), Montero and Dufour (1996) and White and Fernald (1998), the origin of $\mathrm{GnRH} 1$ ancestor and $\mathrm{GnRH} 2$ lineages appears clear and was caused by a $600 \mathrm{MY}$-old gene duplication before the divergence of fish from tetrapods. This would explain the presence of at least two GnRH forms in all classes analyzed to date, with chicken-II type being the most conserved (Dubois et al. 2002). Despite that consistent data relating lineages 1 and 3 exist (e.g. Dubois et al. 2002, Chen \& Fernald 2008), less certainty afflicts the timing of their duplication. Two hypothesis were formulated: as for lineages 1 and 2 , the first one suggests that they originated before the divergence of fish and tetrapods (White \& Fernald 1998, Guilgur et al. 2007, Okubo \& Nagahama 2008), implying that $\mathrm{GnRH} 3$ was either lost or still remains to be described in tetrapods. Conversely, the second one proposes that their duplication occurred within the fish lineage, approximately 320 MYA (Kah et al. 2007), inferring their close relationship. The partially shared anatomical brain localization as well as the similar gene expression patterns that we described (Figs 4 and 5) further confirms the picture. Because of recent evidences supporting the existence of a third fish-specific genome duplication (Christoffels et al. 2004, Meyer \& Van De Peer 2005), the latter hypothesis is favoured. The expected duplicated cGnRH-II form underwent neither specialization nor spatial segregation and was lost because of functional redundancy, as it happens in $50-80 \%$ of cases (Lynch \& Force 2000).
In conclusion, in this study, we delivered crucial information regarding the HPG axis of the European anchovy at its highest level. We established the GnRH forms possessed by this species and characterized them with bioinformatics, molecular and phylogenetic analyses in view of preliminarily assessing the reproductive-relevant variant, describing their tissue localization as well as their temporal pattern of expression and, at last, providing additional details as to the evolutionary development of the three $\mathrm{GnRH}$ lineages. These results lay the groundwork for additional studies aimed at further understanding the reproductive physiology of such an important resource.

\section{Declaration of interest}

The authors declare no conflict of interest that could be perceived as prejudicing the impartiality of the research reported.

\section{Funding}

This work was mainly supported by MEDIAS GAS 17 and GSA 18 research project in the framework of the EC - MIPAAF Italian National Data Collection Programs; the RITMARE National Flagship Project (Italian Ministry for University and Research), SP2_WP1_AZ3_UO01.

\section{Acknowledgements}

EU COST AQUAGAMETE 2012 FA12025 is acknowledged.

The authors acknowledge the captain and crew aboard the R/V Dallaporta during the 2015 MEDIAS research cruise, along with all the researchers and the technical personnel involved in the scientific survey.

MSc student Alessandra Raffa is also acknowledged for her contribution with the tissue specificity analysis.

\section{References}

Abraham E 2004 Studies on reproductive biology and endocrinology in a primitive teleostei, the American shad (Alosa sapidissima). University of Maryland (College Park, MD, USA). Digital Repository at the University of Maryland, http://hdl.handle.net/1903/1725.

Adams BA, Vickers ED, Warby C, Park M, Fischer WH, Grey Craig A, Rivier JE \& Sherwood NM 2002 Three forms of gonadotropin-releasing hormone, including a novel form, in a basal salmonid, Coregonus clupeaformis. Biology of Reproduction 67 232-239. (doi:10.1095/ biolreprod67.1.232)

Allain G, Petitgas P \& Lazure P 2007 The influence of environment and spawning distribution on the survival of anchovy (Engraulis encrasicolus) larvae in the Bay of Biscay (NE Atlantic) investigated by biophysical simulations. Fisheries Oceanography 16 506-514. (doi:10.1111/j.13652419.2007.00442.x)

Amano M, Takahashi A, Yamanome T, Okubo K, Aida K \& Yamamori K 2002 Molecular cloning of three cDNAs encoding different GnRHs in the brain of barfin flounder. General and Comparative Endocrinology 126 325-333. (doi:10.1016/S0016-6480(02)00008-4)

Amoss M, Burgus R, Blackwell R, Vale W, Fellows R \& Guillemin R 1971 Purification, amino acid composition and $\mathrm{N}$-terminus of the 
hypothalamic luteinizing hormone releasing factor (LRF) of ovine origin. Biochemical and Biophysical Research Communications 44 205-210. (doi:10.1016/S0006-291X(71)80179-1)

Andreu-Vieyra CV Buret AG \& Habibi HR 2005 Gonadotropin-releasing hormone induction of apoptosis in the testes of goldfish (Carassius auratus). Endocrinology 146 1588-1596. (doi:10.1210/en.2004-0818)

Baba Y, Matsuo H \& Schally AV 1971 Structure of the porcine LH- and FSH-releasing hormone. II. Confirmation of the proposed structure by conventional sequential analyses. Biochemical and Biophysical Research Communications 44 459-463. (doi:10.1016/0006-291X(71)90623-1)

Basilone G, Bonanno A, Patti B, Mazzola S, Barra M, Cuttitta A \& McBride R 2013 Spawning site selection by European anchovy (Engraulis encrasicolus) in relation to oceanographic conditions in the Strait of Sicily. Fisheries Oceanography 22 309-323. (doi:10.1111/fog.12024)

Bogerd J, Zandbergen T, Andersson E \& Goos H 1994 Isolation, characterization and expression of cDNAs encoding the catfish-type and chicken-Il-type gonadotropin-releasing-hormone precursors in the African catfish. European Journal of Biochemistry 222 541-549. (doi:10.1111/j.1432-1033.1994.tb18896.x)

Bosma PT, Rebers FE, Dijk WV, Willems PH, Goos HJ \& Schulz RW 2000 Inhibitory and stimulatory interactions between endogenous gonadotropinreleasing hormones in the African catfish (Clarias gariepinus). Biology of Reproduction 62 731-738. (doi:10.1095/biolreprod62.3.731)

Carolsfeld J, Scott AP, Collins PM \& Sherwood NM 1996 Reproductive steroids during maturation in a primitive teleost, the Pacific herring (Clupea harengus pallasi). General and Comparative Endocrinology 103 331-348. (doi:10.1006/gcen.1996.0129)

Carolsfeld J, Powell JFF, Park M, Fischer WH, Craig AG, Chang JP, Rivier JE \& Sherwood NM 2000 Primary structure and function of three gonadotropinreleasing hormones, including a novel form, from an ancient teleost, herring*. Endocrinology 141 505-512 (doi:10.1210/en.141.2.505)

Chen CC \& Fernald RD $2008 \mathrm{GnRH}$ and GnRH receptors: distribution, function and evolution. Journal of Fish Biology 73 1099-1120. (doi:10.1111/j.1095-8649.2008.01936.x)

Cheng CK \& Leung PCK 2005 Molecular biology of gonadotropin-releasing hormone (GnRH)-I, GnRH-II, and their receptors in humans. Endocrine Reviews 26 283-306. (doi:10.1210/er.2003-0039)

Christoffels A, Koh EGL, Chia JM, Brenner S, Aparicio S \& Venkatesh B 2004 Fugu genome analysis provides evidence for a whole-genome duplication early during the evolution of ray-finned fishes. Molecular Biology and Evolution 21 1146-1151. (doi:10.1093/molbev/msh114)

Dubois EA, Zandbergen MA, Peute J, Bogerd J \& Th Goos HJ 2001 Development of three distinct GnRH neuron populations expressing two different GnRH forms in the brain of the African catfish (Clarias gariepinus). Journal of Comparative Neurology 437 308-320. (doi:10.1002/cne.1285)

Dubois EA, Zandbergen MA, Peute J \& Goos HJ 2002 Evolutionary development of three gonadotropin-releasing hormone $(\mathrm{GnRH})$ systems in vertebrates. Brain Research Bulletin 57 413-418. (doi:10.1016/S03619230(01)00676-1)

Edgar RC 2004 MUSCLE: a multiple sequence alignment method with reduced time and space complexity. BMC Bioinformatics 5113. (doi:10.1186/1471-2105-5-113)

Felsenstein J 1985 Confidence limits on phylogenies: an approach using the bootstrap. Evolution 39 783-791. (doi:10.2307/2408678)

Fernald RD \& White RB 1999 Gonadotropin-releasing hormone genes: phylogeny, structure, and functions. Frontiers in Neuroendocrinology $\mathbf{2 0}$ 224-40. (doi:10.1006/frne.1999.0181)

Giannoulaki M, Iglesias M, Tugores MP, Bonanno A, Patti B, De Felice A, Leonori I, Bigot JL, Ticina V, Pyrounaki MM et al. 2013 Characterizing the potential habitat of European anchovy Engraulis encrasicolus in the Mediterranean Sea, at different life stages. Fisheries Oceanography 22 69-89. (doi:10.1111/fog.12005)

González-Martínez D, Madigou T, Zmora N, Anglade I, Zanuy S, Zohar Y, Elizur A, Muñoz-Cueto JA \& Kah O 2001 Differential expression of three different prepro-GnRH (gonadotrophin-releasing hormone) messengers in the brain of the european sea bass (Dicentrarchus labrax). Journal of Comparative Neurology 429 144-155.(doi:10.1002/10969861(20000101)429:1<144::aid-cne11>3.0.co;2-b)

Gothilf Y, Elizur A, Chow M, Chen TT \& Zohar Y 1995 Molecular cloning and characterization of a novel gonadotropin-releasing hormone from the gilthead seabream (Sparus aurata). Molecular Marine Biology and Biotechnology 4 27-35.
Gothilf Y, Muñoz-Cueto JA, Sagrillo CA, Selmanoff M, Chen TT, Kah O, Elizur A \& Zohar Y 1996. Three forms of gonadotropin-releasing hormone in a perciform fish (Sparus aurata): complementary deoxyribonucleic acid characterization and brain localization. Biology of Reproduction $\mathbf{5 5}$ 636-645. (doi:10.1095/biolreprod55.3.636)

Gray SL, Adams BA, Warby CM, von Schalburg KR \& Sherwood NM 2002 Transcription and translation of the salmon gonadotropin-releasing hormone genes in brain and gonads of sexually maturing rainbow trout (Oncorhynchus mykiss). Biology of Reproduction 67 1621-1627. (doi:10.1095/biolreprod.102.004788)

Guilgur LG, Ortí G, Strobl-Mazzulla PH, Fernandino JI, Miranda LA \& Somoza GM 2007 Characterization of the cDNAs encoding three GnRH forms in the pejerrey fish Odontesthes bonariensis (Atheriniformes) and the evolution of GnRH precursors. Journal of Molecular Evolution 64 614-627. (doi:10.1007/s00239-006-0125-8)

Hall BG 2013 Building phylogenetic trees from molecular data with MEGA. Molecular Biology and Evolution 30 1229-1235. (doi:10.1093/ molbev/mst012)

Holland MC, Gothilf Y, Meiri I, King JA, Okuzawa K, Elizur A \& Zohar Y 1998 Levels of the native forms of GnRH in the pituitary of the gilthead seabream, Sparus aurata, at several characteristic stages of the gonadal cycle. General and Comparative Endocrinology 112 394-405. (doi:10.1006/gcen.1998.7138)

Ikemoto T \& Park MK 2003. Identification and characterization of the reptilian GnRH-II gene in the leopard gecko, Eublepharis macularius, and its evolutionary considerations. Gene 316 157-165. (doi:10.1016/ S0378-1119(03)00758-3)

Jones DT, Taylor WR \& Thornton JM 1992 The rapid generation of mutation data matrices from protein sequences. Bioinformatics 8 275-282. (doi:10.1093/bioinformatics/8.3.275)

Kah O, Lethimonier C, Somoza G, Guilgur LG, Vaillant C \& Lareyre JJ 2007 GnRH and GnRH receptors in metazoa: a historical, comparative, and evolutive perspective. General and Comparative Endocrinology 153 346-364. (doi:10.1016/j.ygcen.2007.01.030)

Kakizawa S, Kaneko T \& Hirano T 1997 Effects of hypothalamic factors on somatolactin secretion from the organ-cultured pituitary of rainbow trout. General and Comparative Endocrinology 105 71-78. (doi:10.1006/ gcen.1996.6799)

Kim MH, Oka Y, Amano M, Kobayashi M, Okuzawa K, Hasegawa Y, Kawashima S, Suzuki Y \& Aida K 1995 Immunocytochemical localization of sGnRH and $\mathrm{cGnRH}-\mathrm{Il}$ in the brain of goldfish, Carassius auratus. Journal of Comparative Neurology 356 72-82. (doi:10.1002/ cne.903560105)

Kimura M 1980 A simple method for estimating evolutionary rates of base substitutions through comparative studies of nucleotide sequences. Journal of Molecular Evolution 16 111-120. (doi:10.1007/BF01731581)

King JA \& Millar RP 1980 Comparative aspects of luteinizing hormonereleasing hormone structure and function in vertebrate phylogeny. Endocrinology 106 707-717. (doi:10.1210/endo-106-3-707)

King JA \& Millar RP 1992 Evolution of gonadotropin-releasing hormones. Trends in Endocrinology \& Metabolism 3 339-346. (doi:10.1016/10432760(92)90113-F)

Kinoshita M, Kobayashi S, Urano A \& Ito E 2007 Neuromodulatory effects of gonadotropin-releasing hormone on retinotectal synaptic transmission in the optic tectum of rainbow trout. European Journal of Neuroscience 25 480-484. (doi:10.1111/j.1460-9568.2006.05294.x)

Kudo H, Hyodo S, Ueda H, Hiroi O, Aida K, Urano A \& Yamauchi K 1996 Cytophysiology of gonadotropin-releasing-hormone neurons in chum salmon (Oncorhynchus keta) forebrain before and after upstream migration. Cell and Tissue Research 284 261-267. (doi:10.1007/ s004410050586)

Leonori I, De Felice A, Campanella F, Biagiotti I \& Canduci G 2011 Assessment of small pelagic fish biomass in the adriatic sea by means of acoustic methodology. In Marine Research at CNR, pp 2019-2029. Eds E Brugnoli, G Cavaretta, S Mazzola, F Trincardi, M Ravaioli \& R Santoleri.

Leonori I, Ticina V, De Felice A, Vidjak O, Grubišić L \& Pallaoro A 2012. Comparisons of two research vessels' properties in the acoustic surveys of small pelagic fish. Acta Adriatica 53 389-398.

Letunic I, Doerks T \& Bork P 2015 SMART: recent updates, new developments and status in 2015. Nucleic Acids Research 43 D257-D260. (doi:10.1093/nar/gku949) 
Lin XW \& Peter RE 1997 Cloning and expression pattern of a second [His5Trp7Tyr8] gonadotropin-releasing hormone (chicken $\mathrm{GnRH}$ H-II) mRNA in goldfish: evidence for two distinct genes. General and Comparative Endocrinology 170 262-272. (doi:10.1006/ gcen.1997.6920)

Lin XW, Otto CJ \& Peter RE 1998 Evolution of neuroendocrine peptide systems: gonadotropin-releasing hormone and somatostatin. Comparative Biochemistry and Physiology Part C: Pharmacology Toxicology and Endocrinology 119 375-388. (doi:10.1016/S07428413(98)00025-5)

Lovejoy D, Fischer WH, Ngamvongchon S, Craig G, Nahorniak CS, Peter RE, Rivier JE \& Sherwood NM 1992 Distinct sequence of gonadotropin-releasing hormone $(\mathrm{GnRH})$ in dogfish brain provides insight into GnRH evolution. PNAS 89 6373-6377. (doi:10.1073/ pnas.89.14.6373)

Lynch M \& Force A 2000. The probability of duplicate gene preservation by subfunctionalization. Genetics 154 459-473. (doi:10.1371/journal. pgen.0040029)

Madden T 2003 The BLAST sequence analysis tool. 2013 Mar 15. In: The NCBI Handbook [Internet]. 2nd edition. Bethesda (MD): National Center for Biotechnology Information (US)

Maney DL, Richardson RD \& Wingfield JC 1997 Central administration of chicken gonadotropin-releasing hormone-II enhances courtship behavior in a female sparrow. Hormones and Behavior 32 11-18. (doi:10.1006/hbeh.1997.1399)

Matsuo H, Baba Y, Nair RMG, Arimura A \& Schally AV 1971 Structure of the porcine $\mathrm{LH}$ - and FSH-releasing hormone. I. The proposed amino acid sequence. Biochemistry and Biophysical Research Communications 43 1334-1339. (doi:10.1016/S0006-291X(71)80019-0)

MEDIAS 2012. MEDIAS handbook. Common protocol for the PanMEditerranean Acoustic Survey (MEDIAS), March 2012.

Medits Working Group 2012. International bottom trawl survey in the Mediterranean Instruction manual Version 6.

Meyer A \& Van De Peer Y 2005 From 2R to 3R: evidence for a fish-specific genome duplication (FSGD). BioEssays 27 937-945. (doi:10.1002/ bies.20293)

Miccoli A, Leonori I, Estonba A, De Felice A, Piccinetti CC \& Carnevali O 2016 Clupeiformes' egg envelope proteins characterization: the case of Engraulis encrasicolus as a proxy for stock assessment through a novel molecular tool. Molecular Phylogenetics and Evolution 100 95-108. (doi:10.1016/j.ympev.2016.04.006)

Millán M 1999 Reproductive characteristics and condition status of anchovy Engraulis encrasicolus L. from the Bay of Cadiz (SW Spain). Fisheries Research 41 73-86. (doi:10.1016/S0165-7836(99)00010-7)

Millar RP 2005 GnRHs and GnRH receptors. Animal Reproduction Science 88 5-28. (doi:10.1016/j.anireprosci.2005.05.032)

Millar RP, Wormald PJ \& Milton RC 1986 Stimulation of gonadotropin release by a non-GnRH peptide sequence of the $\mathrm{GnRH}$ precursor. Science 232 68-70. (doi:10.1126/science.3082009)

Miyamoto K, Hasegawa Y, Nomura M, Igarashi M, Kangawa K \& Matsuo H 1984 Identification of the second gonadotropin-releasing hormone in chicken hypothalamus: evidence that gonadotropin secretion is probably controlled by two distinct gonadotropin-releasing hormones in avian species. PNAS 81 3874-3878. (doi:10.1073/pnas.81.12.3874)

Mohamed JS, Thomas P \& Khan IA 2005 Isolation, cloning, and expression of three prepro-GnRH mRNAs in Atlantic croaker brain and pituitary. Journal of Comparative Neurology 488 384-395. (doi:10.1002/cne.20596)

Montero M \& Dufour S 1996 Gonadotropin-releasing hormones (GnRH) in fishes: evolutionary data on their structure, localization, regulation, and function. Zoological Studies 35149-160.

Nelson JS 1994 Fishes of the world. Journal of the Marine Biological Association 74 987. (doi:10.1017/S0025315400044192)

Ogawa S, Akiyama G, Kato S, Soga T, Sakuma Y \& Parhar IS 2006 Immunoneutralization of gonadotropin-releasing hormone type-III suppresses male reproductive behavior of cichlids. Neuroscience Letters 403 201-205. (doi:10.1016/j.neulet.2006.02.041)

Okubo K \& Nagahama Y 2008 Structural and functional evolution of gonadotropin-releasing hormone in vertebrates. Acta Physiologica 193 3-15. (doi:10.1111/j.1748-1716.2008.01832.x)

Okubo K, Amano M, Yoshiura Y, Suetake H \& Aida K 2000. A novel form of gonadotropin-releasing hormone in the medaka, Oryzias latipes.
Biochemical and Biophysical Research Communications 276 298-303. (doi:10.1006/bbrc.2000.3476)

Okubo K, Sakai F, En LL, Yoshizaki G, Takeuchi Y, Naruse K, Aida K \& Nagahama Y 2006 Forebrain gonadotropin-releasing hormone neuronal development: insights from transgenic medaka and the relevance to X-linked Kallmann syndrome. Endocrinology 147 1076-1084. (doi:10.1210/en.2005-0468)

Okubo K, Yoshiura Y, Amano M, Suetake H \& Aida K 2013 The GnRH system in teleosts. In Aquatic Genomics. Steps Towards a Great Future. Eds N Shimizu, T Aoki, I Hirono \& F Takashima. Tokyo: Springer. (doi:10.1007/978-4-431-65938-9_22)

Pandolfi M, Munoz-Cueto JA, Lo Nostro FL, Downs JL, Paz DA, Maggese MC \& Urbanski HF 2005. GnRH systems of Cichlasoma dimerus (Perciformes, Cichlidae) revisited: a localization study with antibodies and riboprobes to $\mathrm{GnRH}$-associated peptides. Cell and Tissue Research 321 219-232. (doi:10.1007/s00441-004-1055-7)

Parhar IS, Iwata M, Pfaff DW \& Schwanzel-Fukuda M 1995 Embryonic development of gonadotropin-releasing hormone neurons in the sockeye salmon. Journal of Comparative Neurology 362 256-270. (doi:10.1002/ cne.903620208)

Petersen TN, Brunak S, von Heijne G \& Nielsen H 2011 SignalP 4.0: discriminating signal peptides from transmembrane regions. Nature Methods 8 785-786. (doi:10.1038/nmeth.1701)

Powell JF, Zohar Y, Elizur A, Park M, Fischer WH, Craig AG, Rivier JE, Lovejoy DA \& Sherwood NM 1994 Three forms of gonadotropinreleasing hormone characterized from brains of one species. PNAS 91, 12081-12085. (doi:10.1073/pnas.91.25.12081)

Powell JFF, Fischer WH, Park M, Craig AG, Rivier JE, White SA, Francis RC, Fernald RD, Licht P, Warby C et al. 1995 Primary structure of solitary form of gonadotropin-releasing hormone $(\mathrm{GnRH})$ in cichlid pituitary; three forms of $\mathrm{GnRH}$ in brain of cichlid and pumpkinseed fish. Regulatory Peptides 57 43-53. (doi:10.1016/0167-0115(95)00014-3)

Powell JF, Reska-Skinner SM, Prakash MO, Fischer WH, Park M, Rivier JE, Craig AG, Mackie GO \& Sherwood NM 1996 Two new forms of gonadotropin-releasing hormone in a protochordate and the evolutionary implications. PNAS 93 10461-10464. (doi:10.1073/pnas.93.19.10461)

Ramakrishnappa N, Rajamahendran R, Lin YM \& Leung PCK 2005 GnRH in non-hypothalamic reproductive tissues. Animal Reproduction Science 88 95-113. (doi:10.1016/j.anireprosci.2005.05.009)

Rissman EF, Li X, King JA \& Millar RP 1997 Behavioral regulation of gonadotropin-releasing hormone production. Brain Research Bulletin 44 459-464. (doi:10.1016/S0361-9230(97)00226-8)

Roch GJ, Busby ER \& Sherwood NM 2011. Evolution of GnRH: diving deeper. General and Comparative Endocrinology 171 1-16 (doi:10.1016/j.ygcen.2010.12.014)

Saito D, Hasegawa Y \& Urano A 2003 Gonadotropin-releasing hormones modulate electrical activity of vasotocin and isotocin neurons in the brain of rainbow trout. Neuroscience Letters 351 107-110. (doi:10.1016/j. neulet.2003.08.017)

Schally AV, Arimura A, Kastin AJ, Matsuo H, Baba Y, Redding TW, Nair RM, Debeljuk L \& White WF 1971a Gonadotropin-releasing hormone: one polypeptide regulates secretion of luteinizing and follicle-stimulating hormones. Science 173 1036-1038. (doi:10.1126/ science.173.4001.1036)

Schally AV, Arimura A, Baba Y, Nair RMG, Matsuo H, Redding TW, Debeljuk L \& White WF $1971 b$ Isolation and properties of the FSH and LH-releasing hormone. Biochemical and Biophysical Research Communications 43 393-399. (doi:10.1016/0006-291X(71)90766-2)

Schismenou E, Somarakis S, Thorsen A \& Kjesbu OS 2012 Dynamics of de novo vitellogenesis in fish with indeterminate fecundity: an application of oocyte packing density theory to European anchovy, Engraulis encrasicolus. Marine Biology 159 757-768. (doi:10.1007/s00227-0111852-y)

Seeburg PH, Mason AJ, Stewart TA \& Nikolics K 1987 The mammalian $\mathrm{GnRH}$ gene and its pivotal role in reproduction. Recent Progress in Hormone Research 43 69-98. (doi:10.1016/b978-0-12-5711432.50008-3)

Servili A, Lethimonier C, Lareyre J, López-Olmeda JF, SánchezVázquez FJ, Kah O \& Muñoz-Cueto JA 2010. The highly conserved gonadotropin-releasing hormone- 2 form acts as a melatoninreleasing factor in the pineal of a teleost fish, the European sea bass 
Dicentrarchus labrax. Endocrinology 151 2265-2275. (doi:10.1210/ en.2009-1207)

Sherwood N, Eiden L, Brownstein M, Spiess J, Rivier J \& Vale W 1983 Characterization of a teleost gonadotropin-releasing hormone. PNAS $\mathbf{8 0}$ 2794-2798. (doi:10.1073/pnas.80.9.2794)

Sievers F, Wilm A, Dineen D, Gibson TJ, Karplus K, Li W, Lopez R, McWilliam H, Remmert M, Söding J et al. 2011 Fast, scalable generation of high-quality protein multiple sequence alignments using Clustal Omega. Molecular Systems Biology 7 539. (doi:10.1038/msb.2011.75)

Soverchia L, Carotti M, Andreu-Vieyra C, Mosconi G, Cannella N, Habibi H \& Polzonetti-Magni A 2007 Role of gonadotropin-releasing hormone $(\mathrm{GnRH})$ in the regulation of gonadal differentiation in the gilthead seabream (Sparus aurata). Molecular Reproduction and Development 74 57-67. (doi:10.1002/mrd.20484)

Steven C, Lehnen N, Kight K, Ijiri S, Klenke U, Harris WA \& Zohar Y 2003. Molecular characterization of the GnRH system in zebrafish (Danio rerio): cloning of chicken $\mathrm{GnRH}-\mathrm{II}$, adult brain expression patterns and pituitary content of salmon GnRH and chicken GnRH-II. General and Comparative Endocrinology 133 27-37. (doi:10.1016/S00166480(03)00144-8)

Sukhan ZP, Kitano H, Selvaraj S, Yoneda M, Yamaguchi A \& Matsuyama M 2013. Identification and distribution of three gonadotropin-releasing hormone $(\mathrm{GnRH})$ isoforms in the brain of a clupeiform fish, Engraulis japonicus. Zoological Science 30 1081-1091. (doi:10.2108/zsj.30.1081)

Tamura K, Stecher G, Peterson D, Filipski A \& Kumar S 2013 MEGA6: Molecular Evolutionary Genetics Analysis version 6.0. Molecular Biology and Evolution 30 2725-2729. (doi:10.1093/molbev/mst197)

Temple JL, Millar RP \& Rissman EF 2003 An evolutionarily conserved form of gonadotropin-releasing hormone coordinates energy and reproductive behavior. Endocrinology 144 13-19. (doi:10.1210/en.2002-220883)

Trudeau VL 1997 Neuroendocrine regulation of gonadotrophin II release and gonadal growth in the goldfish, Carassius auratus. Reviews of Reproduction 2 55-68. (doi:10.1530/ror.0.0020055)

Untergasser A, Cutcutache I, Koressaar T, Ye J, Faircloth BC, Remm M \& Rozen SG 2012 Primer3-new capabilities and interfaces. Nucleic Acids Research 40, e115. (doi:10.1093/nar/gks596)

Uzbekova S, Lareyre JJ, Guiguen Y, Ferrière F, Bailhache T \& Breton B 2001. Expression of sGnRH mRNA in gonads during rainbow trout gametogenesis. Comparative Biochemistry and Physiology. Part B, Biochemistry \& Molecular Biology 129 457-465. (doi:10.1016/S10964959(01)00347-5)

Uzbekova S, Lareyre JJ, Madigou T, Davail B, Jalabert B \& Breton B 2002 Expression of prepro-GnRH and $\mathrm{GnRH}$ receptor messengers in rainbow trout ovary depends on the stage of ovarian follicular development. Molecular Reproduction and Development 62 47-56. (doi:10.1002/ mrd.10065)

Vickers ED, Laberge F, Adams BA, Hara TJ \& Sherwood NM 2004 Cloning and localization of three forms of gonadotropin-releasing hormone, including the novel whitefish form, in a salmonid, Coregonus clupeaformis. Biology of Reproduction 70 1136-1146. (doi:10.1095/ biolreprod.103.023846)

Volkoff H \& Peter RE 1999 Actions of two forms of gonadotropin releasing hormone and a GnRH antagonist on spawning behavior of the goldfish Carassius auratus. General and Comparative Endocrinology 116 347-355. (doi:10.1006/gcen.1999.7377)

Wańkowska M \& Polkowska J 2009 Gonadotrophin-releasing hormone and $\mathrm{GnRH}$-associated peptide neurobiology from the rearing period until puberty in the female sheep. Journal of. Chemical Neuroanatomy 38 9-19. (doi:10.1016/j.jchemneu.2009.05.003)

Weber GM, Powell JFF, Park M, Fischer WH, Craig AG, Rivier JE, Nanakorn U, Parhar IS, Ngamvongchon S, Grau EG et al. 1997 Evidence that gonadotropin-releasing hormone $(\mathrm{GnRH})$ functions as a prolactinreleasing factor in a teleost fish (Oreochromis mossambicus) and primary structures for three native GnRH molecules. Journal of Endocrinology 155 121-132. (doi:10.1677/joe.0.1550121)

White RB \& Fernald RD 1998. Ontogeny of gonadotropin-releasing hormone $(\mathrm{GnRH})$ gene expression reveals a distinct origin for $\mathrm{GnRH}$ containing neurons in the midbrain. General and Comparative Endocrinology 112 322-329. (doi:10.1006/gcen.1998.7142)

White RB, Eisen JA, Kasten TL \& Fernald RD 1998 Second gene for gonadotropin-releasing hormone in humans. PNAS 95 305-309. (doi:10.1073/pnas.95.1.305)

Wirsig-Wiechmann CR 2001 Function of gonadotropin-releasing hormone in olfaction. Keio Journal of Medicine $\mathbf{5 0}$ 81-85. (doi:10.2302/kjm.50.81)

Yamamoto N, Oka Y \& Kawashima S 1997 Lesions of gonadotropinreleasing hormone-immunoreactive terminal nerve cells: effects on the reproductive behavior of male dwarf gouramis. Neuroendocrinology $\mathbf{6 5}$ 403-412. (doi:10.1159/000127203)

Yaron Z, Gur G, Melamed P, Rosenfeld H, Elizur A \& Levavi-Sivan B 2003 Regulation of fish gonadotropins. International Review of Cytology 225 131-185. (doi:10.1016/S0074-7696(05)25004-0)

Yu WH, Seeburg PH, Nikolics K \& McCann SM 1988 Gonadotropinreleasing hormone-associated peptide exerts a prolactin-inhibiting and weak gonadotropin-releasing activity in vivo. Endocrinology $\mathbf{1 2 3}$ 390-395. (doi:10.1210/endo-123-1-390)

Zohar Y, Muñoz-Cueto JA, Elizur A \& Kah O 2010 Neuroendocrinology of reproduction in teleost fish. General and Comparative Endocrinology 165 438-455. (doi:10.1016/j.ygcen.2009.04.017)

Received 26 July 2016

First decision 10 August 2016

Revised manuscript received 8 September 2016

Accepted 19 September 2016 